\section{Quarrel over share-out}

\section{Sydney}

Australian medical researchers are once again complaining that they have been short-changed by the Australian Research Council (ARC) and, thanks to the way $A R C$ is interpreting a government report, will be left without funds to support their research infrastructure for the next three years.

In its May science budget, the Australian government allocated $\mathrm{A} \$ 107.5$ million for higher education infrastructure. The allocation came in response to the Smith committee's report in March which recommended an increase in infrastructure support. The funds provide for items that are not covered by specific project funds, such as journal acquisition, animalhouse maintenance and the purchase of general equipment. Medical researchers now find that they are ineligible for any part of these funds. Professor Don Aitkin, chairman of both ARC and the working party set up to decide how the funds should be distributed, says "for the ARC to provide research infrastructure to clinical medicine and dentistry would be to provide a certain amount of doubledipping'. The National Health and Medical Research Council (NH \& MRC) received a separate allocation of $\$ 25$ million to be spent over three years on "public health, training and equipment" in the May budget. Medical researchers had understood this money to be earmarked for new UK RESEARCH COUNCILS

\section{New secretary for NERC}

\section{London}

DR EILEen Buttle will become secretary of Britain's Natural Environment Research Council (NERC) on 18 September. Buttle,

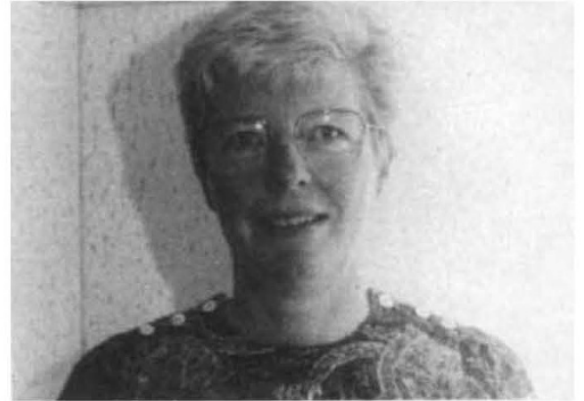

who leaves the Ministry of Agriculture, Fisheries and Food (MAFF) where she is head of the Conservation Policy Division, was Establishment Officer at NERC from 1985 to 1988 . She has a PhD for study in marine zooplankton, has worked at the Pig Industry Development Authority and the National Institute for Research in Dairying, MAFF and has joined the Civil Service Senior Professional Administrative Training Scheme.

Ben Webb projects and scholarships; ARC believes it should be used to maintain research infrastructure.

"If we did use the money for infrastructure, then we would have a static budget allocation over the next three years, which makes no sense", said Professor John Coghlan, chairperson of the Medical Research Committee of NH \& MRC, and deputy vice-chancellor (research) at the University of Melbourne. "The working party misunderstood the [May] budget statement".

Medical researchers' problems are compounded by an earlier budget redistribution. Last year, the Minister for Education, John Dawkins, announced that A $\$ 125$ million would be pulled out of the universities over three years and distributed competitively by ARC. The clawback, as it is termed, was to be taken out of operating grants. According to Professor Ian McLoskey, head of the faculty of medicine research committee at the University of New South Wales, "the money was taken out of operating grants and redistributed as project grants. When competing for project grants, it must be specified that infrastructure funding is already available. Where will that money come from?"

The Smith committee advised that medical research, which makes up 20 per cent of all research at universities, should receive 20 per cent of the clawback as competitive grants. ARC decided, however, to release only 10 per cent for medical research. While researchers were unhappy with this deal, worse was to come.

ARC interpreted the Smith committee directive to mean 10 per cent of the increase in funds, instead of 10 per cent of the total; this means that in 1990 , when clawback funds go up from $\mathrm{A} \$ 20$ million to $\mathrm{A} \$ 40$ million, medical researchers will receive only $A \$ 2$ million, rather than the A \$4 million they expected.

According to Professor McLoskey, the A $\$ 2$ million shortfall "accounts for 50 new projects a year out of a total of 750 . This A $\$ 2$ million is likely to hit the little battlers of medical research rather than block grants for institutions." There has long been tension between medical researchers and ARC. Medical researchers resent having their funding determined by a committee which grants them no representation. According to Professor David Penington, vice-chancellor of the University of Melbourne, the ARC's agenda is to reduce funding for high-profile areas such as medicine. "Professor Aitkin holds the belief that medicine has done well enough for long enough and, in the name of equity, they must give up some of their money to less high-prestige areas", he said.

Tanla Ewing

\section{Jackson Lab should stand on its own feet}

\section{Washington}

THE US National Institutes of Health (NIH) have indicated that they will not gladly accept money to reestablish the colonies of genetically inbred mice that were wiped out during the fire at Jackson Laboratory in Bar Harbor, Maine, in May (see Nature 339, 169; 1989).

Before its August recess, the Senate passed legislation introduced by Senator Edward Kennedy (Democrat-Massachusetts) authorizing a $\$ 25$ million grant for the construction of a laboratory mouse-breeding facility, to be administered by NIH.

But NIH contend that as a private company, Jackson Laboratory should use its insurance money and other resources to recover on its own, without federal assistance. A policy statement prepared by NIH says that even if Congress allocates money for a facility to NIH, "the agency has a number of pressing needs for which the funds could be used". Breeding stock for the 1,700 strains of mice bred at Jackson Laboratory were saved from the fire; the company hopes to achieve half its production capacity before the fire within the next six months.

Carol Ezzell

SATELLITES

\section{First commercial launch in US}

\section{Washington}

THE successful launch on 27 August of Marcopolo 1, a British communications satellite that will transmit television programming for British Satellite Broadcasting Ltd from a geostationary orbit above the Atlantic Ocean, marked the entry of McDonnell Douglas, the US aerospace corporation, into the field of commercial rocketry. Marcopolo 1, launched by a Delta 187 rocket from Cape Canaveral, went into space ahead of India's Insat 1-D, which was damaged on the launch-pad in June (see Nature 339, $649 ; 1989)$. The Indian satellite is under repair, and may now be ready for launch next spring.

McDonnell Douglas has been building rockets for the National Aeronautics and Space Administration (NASA) for decades. Its entry into commercial space activities was prompted by the Challenger shuttle explosion of 1986, which rendered NASA, until then responsible for all payload and manned launches, temporarily impotent. President Reagan then directed the US Air Force to put satellites into orbit using its fleet of expendable launch vehicles (ELVs), and also encouraged ELV manufacturers to offer their services commercially. McDonnell Douglas, along with Martin Marietta and General Dynamics, has dozens of commercial launches planned for the next few years.
David Lindley 